\title{
The Effect of Punishment on Elementary Students in the Islamic School
}

\section{Widyastuti}

Tadris Bahasa Inggris, FTIK, Institut Agama Islam Negeri (IAIN) Salatiga, Central Java, Indonesia

widyastuti.jati@yahoo.com

\begin{abstract}
This study aims to provide understanding about school's perceptions of discipline and punishment for elementary students in Bawen and Ambarawa region. This research used qualitative method to collect the data. The datas was collected by questionnaire and observation. The participants consist of students and their parents, also the teachers of elementary school in Bawen and Ambarawa regions. From the observation could get some different perception about punishment to the children or student in the form. The data collected by some classification, so it obtained a decision of their opinion. The results showed that the physical and verbal punishment as in various forms in classroom for discipline programs. When the students broke the rules, they would be subject to discipline. Actually, punishment had some negative side effects to them. The students who were the object of punishment would showed a bad attitude towards to their teachers and friends. It could be concluded that punishment is humanistic and educative punishment and the least effective of punishment was authoritarian and non- educative punishment. The teacher should give punishment which would give an educational effect to their student. So, they would get an educational advantages from it.
\end{abstract}

Keywords: effectiveness, punishment, discipline, students, educative punishment 


\section{INTRODUCTION}

The conventional elementary school concept of discipline is based on obedience (Gartrel, 1997: 34; Heitmann et al., 2017: 2). Some parents and teachers contemplated a punishment as a part of discipline implementation. In Indonesia, there was an elementary school teacher gave the unreasonable punishment to their students. They used a punishment and disciplinary action in physical by teachers or school administrators as for some student example, spanking, slapping, and pinching.

The other of inappropriate punishments, they had to write a hundred same sentences or sent them to an empty room, cleaning the toilet, standing up in front of the class, running around the school yard. The teachers also threated and reproached students without though about fear or depressed feeling. The student behavior problems had been as a major concern of teacher, administrators, and parents, but they should be wise with the students (Kayiwa et al., 2017). So, their problems could be solved better. The purpose of this study was focus on type of discipline models for elementary student. This research understood about the necessary of punishment in school and kinds of punishment models that should be used for elementary students (Kayiwa et al., 2017: 86).

The school environment had to be comfort for elemetary students. There were five factors of school environment: Safety, Relationships between Teaching and Learning, Institutional Environment and the School Improvement Process (Thapa, 2013). Students will feel exciting in 
their school if they are free for playing and joking with their friends, without fearing and stressing, they have good relationship with their teachers, enjoy the lesson and the condition of the class and school are comfortable.

In the school improvement process, the role of parents are very important. The most important factors according to student's prestige in school is about parents activities involved in their education process (Schneider, 2018: 12). The policies of school should be communicated with parents, and the school perform activities that can be done by teachers and parents for examples parents teacher conferences, fund raising event, foster communication and social ties between families and school personnel or informal networking between teacher and parents. So from this network the parents can frequently interact, they can share information, new school policies or express complain to school.

A discipline form can be called effective if plan can be understood by students, teachers and parents can lead to student success easily. Establishing an effective discipline plan will ensure order and maintain. School discipline practices were informed by theory from psychologists and educators. Discipline is not same with punishment concentrating and consequences. It may be referred to as positive discipline or guidance. The aims of discipline is about the student can be responsible for their action.

The principles of positive disciplines for elementary schools students guiding, teaching, understanding, patience, and solving their problem. To implicate six positive discipline the teacher should do non- 
verbal Redirection, conferencing with students and parents contact. Punishment gave an effect as psychological and action caused of pain. If the goal for the child is the development of morality, of making good choices on his or her own, then punishment should not be involved. Condition should be created that not only allow but strongly induce children to be or become moral and disciplined individuals who can make good choices on their own. Punishment teaches a child that those who have the power can force others to do what they want them to do. Punishment stops behavior temporally, but the behavior is often repeated in other setting. Teacher should understand the pros and cons about using punishment in the classroom, as schools frequently build punishing, or aversive, consequences into plans designed to help manage student behaviors.

Punishment can take various practices in classroom discipline lists. Teachers found punishment to be effective as classroom behavior tool, especially in the problem of behaviors, the teacher in turn is positively reinforced for using it. In theory of Learning, punishment is a way to overcome a behavior to fit the expected behavior (Kunlasomboon et al., 2015: 238; Staddon, 2017: 218). It relies on behaviorists approach: if behavior is reinforced it will continue and if it is not reinforced it will stop (Cheung et al., 2006). Some experts said that the approach is great if we are training rats and pigeons but not when dealing with students. Students may learn bad behavior has consequences but they are not learning how to 
behave better. Before using punishment techniques, the teacher should consider whether

In this research, researcher found that the violence against students in Elementary School not only physical and aggrieving task but also verbal violence. Verbal violence had not been discussed by the previous researcher yet, so hopefully this research will complete the research about punishment in schools.

\section{METHODS}

This research used qualitative research that analyzed by nonnumerical data. It stated that descriptive surveys concerned with finding out. Its strength is on investigating the present status of phenomena being studied. Individual interviews and review of other available materials. The respondents to the study included 20 students, 6 teachers, 6 parents and 2 headmasters. The outcomes of the quantitative data from the questionnaire were analyzed using descriptive statistics. On the other hand, the qualitative data generated from interview guide was presented in a narrative form.

\section{DISCUSSION}

\section{Study Case}

There were former researchers presented some previous researches dealing with discipline and punishment to complete the researchers' study. 
Teachers identified that punishment gave negative effect to the student and their personality. Other teachers believed that they punished their students due to the pressure and experience. Some student said that they had advanced in fear, frustration, aggression, low self- esteem, low confidence and lacked motivation for learning as result of the continuous punishment. So that, punishment (physical or verbal) on student in schools is reflection poor teaching and discipline.

From the observation, there was very rare to no procedural and recommended corporal punishment. Corporal punishment has been found to be effective in temporally controlling deviant behavior in pupils. Restraining deviant behavior was not guarantee that the behavior would automatically be eradicated and this control was short-lived. Therefore corporal punishment has been found to be effective in temporally controlling deviant behavior in pupils. So, corporal punishment has been found to be ineffective in deviance eradication. It was recommended that school should widen and diversity their disciplinary strategies, include positive discipline, reward, discussion, explanation and others.

The other side, individual achievement of the learning process referred to academic achievement. To achieve the academic achievement, discipline in learning is needed, but learn to discipline is not easy therefore students who violate discipline should be punished, but punishment tends to negatively affect students and it is not a method or tool to make students discipline. Beside that punishment does not guarantee students to be obedient the rule or discipline. So, punishment 
should be educational that motivate students become creative, intelligent, imaginative and productive.

Results

Schools are educational Institution where students follow the learning process and prepare themselves to face the future. So it is not a court that is in charge of punishing the guilty students, this does not mean that students who makes mistakes are not given an act. The data that researcher got from the newspaper, television and interviewed with some headmasters, teachers, students and parents of elementary school students, the researcher still found violence against students either physical, verbal or aggrieving task.

Some interviewed teachers said that punishment could be physical or verbal and it meant to correct students' misbehavior and maintain discipline in classroom. The teachers punish their pupils as this will make them obedient and ready to do their assigned exercises in time. Most teacher complain about the irritating behavior of the students, for example students behave in tough ways towards each other in school yard and in classroom, noise and disobedience. In such situation teachers hit and beat using sticks to maintain school discipline. The interviewed teachers said, punishment gave transformation in the learners' behavior and help teacher to control the class. But, it gave a change produced through punishment are a temporary change, and punished students especially boys return back to unwanted behavior. 
The outcomes was confirmed about the child psychologists, educational psychologists, behavioral learning theories, rights activists and researchers that corporal punishment side effect on student behavior and self-esteem is exceeding its positive effectiveness in correcting misbehavior (Kilimici, 2009: 243). Meanwhile some teachers also do Verbal punishment. Usually it was done by teacher to correct misbehaviors in class, in verbal punishment or verbal violence, teacher uses verbal language to embarrass, mock or insult students, the words that they said are stupid, naughty, ugly, hopeless,"otak udang”, dirty etc. The other examples of verbal violence are focusing, threatening, ordering, trivializing, blaming, name calling and overtly criticizing.

The reaction of the students were lose their concentration during class, escaping from the school, shame, anxiety, hatred to the lesson and teacher, frustrating, low self- esteem, sad, inferior, aggressive, less confident. Some interviewed teachers said that they rarely and never use physical punishment in their classes. They tend to use other alternative and found their effectiveness in correcting student's behavior, for example not go for the break and stay inside the class to write and complete the homework, cleaning board in a week, taking exercise books to office, telling a story or joke (Indrayati, 2017: 38). This punishment does not create sense of fear, aggression, hatred and isolation to learners but it is useful for them.

Many schools focus more on punishment than on guidance. Beside that the rules are made sometime excessive that makes the space for 
students is limited so that the creativity does not improve. There should be a practical mechanism to follow the practice of education policies. According a headmaster of elementary school in Ambarawa, children should be aware of their rights and their shared responsibility in contributing to maintain discipline in schools. The training of the teachers to raise their knowledge on making their teaching effective and attractive through the use alternative discipline is an urgent issue. In children education, teachers should apply some different methods for other situations. Teachers should had to be a good partners with student in learning rather than bosses. Learning should be structured so that children enjoy what they are doing while learning. According to behavior problems and disciplinary, teacher should have to provide the learning activities. In the other side, the activity allowed the student to think, correcting their mistakes and develop understanding, provide a positive, non-threatening teaching environment. If the student do misbehavior problems, teachers must communicate with parents.

Teacher should consider the side effects of punishment and its harmful consequences on children behaviors in future life. It is important examining children behavior problem and solving them through the positive support and procedures rather than using punishment as tool of discipline in school. Comprehensive School-wide Plan is one of effective method that prevent punishment in elementary school. The method is suitable with The Holy Qur'an Ali Imran.134 Those who spend (freely), whether in prosperity or in adversity; who restrain anger and pardon (all) 
men; for God loves those who do good. And in Hadith, prophet Muhamad taught that God loves tenderness, in all problems (HR. Bukhari).

So, as a teacher in an Islamic elementary Schools, should agree that the mistake made by the students sometimes deserve punishment, but the type of punishment should be adapted to school environment as means of education and learning, not judgement. A comprehensive school-wide plan consists of a full range of evidence-based strategies and techniques to achieve four important goals in developing self-discipline, preventing, correcting, sand remediating and responding to serious behavior problem.

Self-discipline is seen in socially and morally responsible behavior that is motivated primarily by intrinsic factors, not solely by the anticipation of external rewards or fear of punishment. Research showed that self-discipline gave positive relation with others and school climate, foster academic achievement. Strategies for developing self-discipline are commonly part of evidence-based programs for character education and for social and emotional learning. Such program include the following strategies: (1) Curriculum Implementation activities that teach social, emotional, and behavioral competition; (2) Provide multiple models of social and moral problem solving and responsible behavior, multiple models of targeted behavior, social cognitions and emotions should be included in the school's curriculum (e.g. literature, video) and more important in the real life of the classroom and school (3) Provide multiple opportunities for students to apply skills of social and moral problem- 
solving and responsible behavior. Such opportunities would include classmeeting, meaningful student government activity (e.g. helping others in community), program and activity for conflict resolution, peer mediation, service learning, cooperative learning, sports and extracurricular activity.

Authoritative teachers see high standards and high expectation enforce rules and standards in a firm, fair and consistent manner and promote autonomy by encouraging students' active participation in decisions regarding their behavior. Although authoritative teacher, punitive and reactive strategies when needed, the focus more on the use of positive, proactive. The example of punitive techniques, unpleasant verbal reprimands, 'the evil eye", proximity control (i.e. standing near the students) the examples of reactive strategies: direct instruction, positive reinforcement, modeling, social problem solving conflict resolution and anger management training.

The effective teachers can improve a positive relationship with student in their classrooms and seek to promote positive relationships and sense of community among the students themselves; (1) Establish and maintain close communication with each student's parent or caregivers and work hard to garner the parent's support; (2) Provide academic instruction and activities that motivate learning; (3) Creating a conducive physical environment; (4) Monitoring student's behavior and respond it; (5) Using a praise and rewards to improve behavior (Budiman, 2017: 112). 
Authoritative style of discipline not only prevention of behavior problems but also their correction. Disciplinary happenstances not merely as situation that may require punishment as a means of correction, but as opportunities to teach appropriate behavior and help develop selfdiscipline and prevent future behavior problems. Authoritative educators combined receptiveness with no demand. When correcting misbehavior, the teachers should work hard to avoid using punishment. Instead they focus in strategies in developing self- discipline and for preventing misbehavior. When correcting misbehavior they should be much more likely to use mild forms of punishment such as verbal reprimands, "the evil eye", recite short part of The Qur'an, writing or making composition, poem/poetry, making/ retelling summary of book which are better than punishment. When punishment was used, it would be fairly, judiciously in the context of caring and supportive relationship.

Students with long-lasting or serious behavior problems and especially those shown to be resistant to interventions, require more comprehensive and intensive services, resources and support. The strategies and techniques used for chronic and serious problems, similar with the strategies of correcting misbehavior but delivered in more frequent and systematic fashion. Teachers should give more targeted and intensive strategies, they should more comprehensive in responding misbehavior students, teachers must work together with head master, counselling teachers and students parent. 


\section{CONCLUSION}

The type of discipline that should be used for Elementary School are positive discipline. (a) guiding and teaching (b) is done with child (3) requires understanding, time and patience $(\mathrm{d})$ teaches problem solving and build positive self-image develop long term self-control and cooperation ( $f$ ) consistence.

Punishment, physical and verbal was necessary but it must be educational punishment. Teachers should understood about the negative effects of punishment and its consequences on student's behaviors life. It was important examining children behavior problem and solving them through the positive support and procedure rather than using punishment as tool discipline in school. If the teacher should punish the misbehavior students, the punishment must be educational and avoid sense of fear for examples recite part of the Holy Qur'an, writing composition /poem/poetry, drawing, reading book then summarize or retell, do more homework, cleaning board in a week etc. Teacher should not use verbal violence but should give advice or motivation that make the students feel regret and will not repeat their misbehavior.

\section{REFERENCES}

Gartrel. (1997). Beyond Discipline to Guidance: Young Children, 52 (6) 34 42.

Thapa Amrit, Jonathan Cohen, Shawn Guffey. (2013). A review of School Climate Research: Review of Educational Research, 83 (3), 357-385. 
Mudarrisa: Jurnal Kajian Pendidikan Islam, Vol. 11, No. 1, 2019

Schneider Barbara and James S. Coleman. (2018). Parents, Their Children, and School. New York: Taylor \& Francis.

Kilimici, S (2009). Teachers'perceptions on corporal punishment as a Method of discipline in elementary School: The Journal of International Social Research, 2(8), 242-251

Budiman, A. (2017). Behaviorism in Foreign Language Teaching Methodology, English Franca, 1(2), 101-114.

Cheung, K. C., Taylor, R., Cheung, K. C., \& Taylor, R. (2006). Towards a humanistic constructivist model of science learning: changing perspectives and research implications. Journal of Curriculum Studies, 23, 37-41.

Heitmann, P., Hecht, M., Scherer, R., \& Schwanewedel, J. (2017).

Learning Science Is About Facts and Language Learning Is About Being Discursive- An Empirical Investigation of Students' Disciplinary Beliefs in the Context of Argumentation: Frontiers in Psychology, 8.

Indrayati. (2017). The Implementation Of PAIKEM Based on ProjectBased Learning and Cooperative Learning: IOSR Journal of Humanities and Social Science, 22(7), 37-43.

Kayiwa, J., Clarke, K., Knight, L., Allen, E., Walakira, E., Namy, S., Devries, K. (2017). Effect of the good school toolkit on school staff mental health, sense of job satisfaction and perceptions of school climate: Secondary analysis of a cluster randomised trial: Preventive Medicine, 101, 84-90. 
Mudarrisa: Jurnal Kajian Pendidikan Islam, Vol. 11, No. 1, 2019

Kunlasomboon, N., Wongwanich, S., \& Suwanmonkha, S. (2015).

Research and Development of Classroom Action Research Process

to Enhance School Learning: In Procedia-Social and Behavioral Sciences, 171, 1315-1324.

Staddon, J. (2017). Theoretical Behaviorism: In In Behavior and Philosophy, 217-241. 